\title{
Herdeiros necessários
}

\author{
Fabrício Dani de Boeckel*
}

\section{INTRODUÇÃO}

A recente entrada em vigor do novo Código Civil produziu inúmeras alterações no ordenamento jurídico brasileiro. O direito sucessório, embora tenha sofrido modificações em grande parte menos significativas que outras áreas do direito civil, também teve seu conteúdo atingido pela nova legislação.

Dentre as inovações introduzidas no direito das sucessões, merece destaque a inclusão do cônjuge no rol dos herdeiros necessários e a previsão de concorrência do mesmo com os descendentes do falecido em determinadas condições, bem como a concorrência com ascendentes na falta de descendentes. Essa alteração, porém, acarretou a necessidade de uma série de adaptações.

Procuraremos, no presente trabalho, abordar a matéria relativa aos herdeiros necessários, sempre à luz da nova ordem jurídica estabelecida.

Com esse objetivo, após um breve relato histórico, passaremos a analisar a definição de "porção legítima", bem como a forma pela qual deve a mesma ser calculada, posteriormente entrando na matéria relativa ao elenco de herdeiros necessários segundo o novo Código Civil.

Estudados os pontos acima referidos, poderemos entrar em outros que possuem direta relação com o tema da garantia conferida aos herdeiros reservatários, quais sejam: o instituto da colação, destinado a igualar, na proporção estabelecida no Código, a legítima de certos herdeiros necessários, e as restrições que podem ser impostas sobre os bens hereditários através de testamento, especialmente a clausulação dos bens integrantes da legítima.

\footnotetext{
* Advogado, mestre em Direito pela UFRGS, professor substituto da Faculdade de Direito da UFRGS.
} 
Em síntese, procuraremos estabelecer as novas bases sobre as quais deve ser estudado o tema alusivo aos herdeiros reservatários, adaptando os antigos institutos às inovações recentes e propondo as reformulações necessárias.

\section{BREVE RELATO HISTÓRICO}

A liberdade de dispor dos bens por testamento seguiu caminhos inversos na história da civilização ocidental. De um lado, o direito romano, admitindo inicialmente a ampla e irrestrita liberdade de testar, fundada no poder ilimitado do pater familias; de outro, o direito germânico, que em razão da tradição da co-propriedade familiar impedia a transmissão dos bens hereditários a alguém estranho à família, impondo a atribuição da herança ao primogênito. ${ }^{1}$

Ao longo do tempo, todavia, essas posições extremadas foram gradativamente se aproximando. No direito romano, o primeiro passo foi estabelecer aquilo que os autores costumam chamar de um "direito hereditário necessário formal", isto é, impor ao disponente a necessidade de excluir expressamente cada um dos parentes próximos que não desejasse contemplar. O passo seguinte foi a utilização da querela inofficiosi testamenti como meio de proteção dos parentes próximos, anulando-se o testamento que não os contemplasse, tudo com base na ficção de que o testador não poderia estar em seu perfeito juízo ao excluir de sua sucessão pessoas que presumivelmente eram a ele ligadas por estreitos laços afetivos. ${ }^{2}$

Arnoldo Wald relata que a atenuação desse rigorismo (anulação do testamento como um todo) decorreu de um senatus consultus da época de Marco Antônio, quando foi proibida a utilização da querela inofficiosi testamenti nos casos em que os parentes próximos recebessem ao menos uma quarta parte da herança. Não mais se admitia a anulação do testamento em função da alegação de insanidade do testador, apenas permitindo-se a redução das disposições na quantidade suficiente para que fosse respeitada aquela quota em favor dos parentes próximos.

No direito justinianeu já havia previsão expressa dessa proteção aos descendentes, ascendentes e irmãos, em limite até mais benéfico a esses parentes: a parte indisponível corresponderia a um terço do patrimônio hereditário quando o testador possuísse quatro filhos ou menos e à metade quando tivesse número maior de filhos. Outro ponto relevante da regulação da liberdade de testar foi a previsão, na Novela 115, da exigência de justificação expressa e plausível para a deserdação, inclusive estabelecendo as

1 PONTES DE MIRANDA, Francisco Cavalcanti. Tratado de direito privado. Rio de Janeiro: Borsoi, 1968, v. 55, p. 205-211.

2 MIRANDA, Darcy Arruda. Da "legítima" na sucessão testamentária. Revista Trimestral de Direito Privado, São Paulo, v. 1, p. 149-158, 1970, p. 150.

3 WALD, Arnoldo. Direito das sucessões. 12. ed. rev., ampl. e atual., com a colaboração do Prof. Roberto Rosas e da Profa. Débora Gozzo. São Paulo: Saraiva, 2002, p. 165. 
causas que dariam ensejo à essa espécie de exclusão do herdeiro. ${ }^{4}$

Portanto, seguindo os passos sumariamente relatados atinentes à evolução romana, conclui-se que a mesma partiu de uma posição inicial na qual se atribuía total liberdade de dispor dos bens por testamento, situação que foi sendo restringida ao longo do tempo, estipulandose cada vez maiores garantias aos parentes próximos contra o arbítrio e a ampla liberdade do testador.

Em sentido completamente inverso ocorreu a evolução do direito germânico. Como já mencionado, a tradição de que o patrimônio pertencia à família, não podendo ser dela afastado por vontade do testador, que deveria transmitir os bens ao primogênito, impossibilitava toda e qualquer liberdade de disposição. Aqui a evolução ocorreu no sentido de permitir, gradativamente, cada vez maior liberdade ao testador para disciplinar a transmissão do patrimônio.

Seguindo esses caminhos inversos, chegou-se na modernidade a um meiotermo: de um lado, é oferecida proteção aos parentes próximos contra o arbítrio do testador, garantindo-lhes a participação em determinada quota da herança; de outro, admite-se a livre disposição de certa fração do patrimônio, sem necessidade de mencionar o porquê de sua vontade, permitindo-se que em relação a essa parte o testador exerça inteiramente o seu arbítrio.
Contudo, apesar da enorme aproximação verificada, muitas diferenças ainda existem no tratamento da matéria pelos Estados contemporâneos. A quota disponível, os herdeiros aos quais é garantida a parte reservada, as condições para a deserdação, a possibilidade de imposição de certas restrições sobre a legítima, entre tantos outros pontos, recebem tratamento bastante diferenciado nos ordenamentos jurídicos da atualidade.

No século XIX, vigorava em nosso país regra que garantia aos herdeiros necessários uma quota correspondente a dois terços da herança. O Projeto Beviláqua, de 1889 , seguiu essa mesma orientação. Porém, em 1907, através da Lei Feliciano Pena, a parte indisponível foi reduzida para metade do patrimônio hereditário, ${ }^{5}$ limite que foi mantido pelo Código Civil de 1916 e também pelo de 2002. O novo Código Civil, todavia, trouxe algumas inovações em relação ao rol dos herdeiros necessários, à possibilidade de imposição de certas restrições à legítima, entre outros aspectos que analisaremos adiante.

\section{DEFINIÇÃO E CÁlCULO DA LEGÍTIMA}

Inicialmente convém distinguir algumas das inúmeras acepções em que o termo "legítima" é utilizado no ordenamento jurídico brasileiro, destacando especialmente três sentidos bastante

4 VENOSA, Sílvio de Salvo. Direito civil: direito das sucessões. 3. ed. São Paulo: Atlas, 2003, p. 203.

5 RODRIGUES, Sílvio. Direito civil: direito das sucessões. 25. ed. atual. por Zeno Veloso. São Paulo: Saraiva, 2002, p. 123. 
diversos: a) num primeiro momento, o legislador pátrio refere-se à "sucessão legítima", como contraponto à sucessão testamentária. Nesse sentido, está aludindo à sucessão que se dá pela ordem de vocação hereditária prevista na lei (não em testamento) e segundo a distribuição de quotas na proporção também decorrente das disposições legais. Os herdeiros assim chamados a suceder são denominados "herdeiros legítimos"; b) a segunda acepção utilizada pelo legislador diz respeito à metade indisponível do patrimônio, ou seja, àquela parte da herança que a lei reserva a determinadas pessoas presumivelmente ligadas ao testador por fortes laços afetivos, limitando a sua liberdade de disposição. Orlando Gomes destaca que a proteção à legítima, contudo, não ocorre apenas no direito sucessório, fazendo-se presente também nos atos inter vivos através dos quais determinado indivíduo pretenda doar uma quota de seu patrimônio superior ao limite que, naquele momento, poderia dispor pela via testamentária ${ }^{6}$ c) o termo "legítima" é também utilizado para designar a fração correspondente a cada herdeiro legítimo. Nesse caso, é possível o emprego do termo no plural, referindo-se às quotas dos diversos herdeiros chamados a suceder pela ordem e na proporção estabelecida na lei, ao contrário do significado mencionado sob a letra "b", segundo o qual apenas é admissível conceber uma "legítima" (metade indisponível), que se contrapõe à quota disponível.

Feita essa primeira distinção, limitaremos agora nossa análise apenas à segunda acepção referida (letra "b"), ou seja, "legítima" como a parte indisponível do patrimônio, reservada obrigatoriamente aos herdeiros necessários, os quais não podem ser afastados da sucessão, exceto em casos de tamanha gravidade, quando então o legislador permite a exclusão da herança (seja por indignidade, seja por deserdação).

Como já foi referido, o emprego do termo em pauta com o significado que tem relevância para o presente trabalho jamais poderá ser utilizado no plural, pois no máximo existirá uma metade legítima em cada sucessão, possuindo o testador livre disposição sobre a metade remanescente. Destaque-se, porém, que nem sempre haverá essa reserva, pois a mesma tem como destinação específica proteger os herdeiros necessários contra o arbítrio do testador, não se configurando na hipótese de o falecido não deixar sucessores pertencentes às classes que gozam desse benefício, como implicitamente determina o art. 1.789 do novo Código Civil: "Havendo herdeiros necessários, o testador só poderá dispor da metade da herança".

6 GOMES, Orlando. Sucessões. 7. ed. atual. por Humberto Theodoro Júnior. Rio de Janeiro: Forense, 1998, p. 75. Idêntico ensinamento nos passa Giovanni Cribari (CRIBARI, Giovanni. Sucessão testamentária - Herdeiros necessários - Força da legítima - Doação em vida: limites - Ações de empresa familiar holding: sobrevalor. Revista Forense, Rio de Janeiro, v. 331, p. 185/195, 1995.p. 192). 
Mais uma distinção deve ser feita nesse momento: os herdeiros legítimos nem sempre serão necessários. É o caso, por exemplo, dos colaterais, mencionados na ordem de vocação hereditária pelo direito pátrio, porém não abrangidos pela reserva de parte do patrimônio em seu favor, o que lhes asseguraria direitos sucessórios mesmo contra a vontade do testador. Os herdeiros necessários, pelo contrário, sempre serão herdeiros legítimos, isto é, aqueles que são chamados segundo a ordem de vocação fixada na lei.

Se as disposições realizadas pelo testador em vida ou por ato de última vontade não atingirem a totalidade da parte disponivel, a soma das quotas recebidas pelos herdeiros necessários será superior ao valor da legítima, no sentido de metade indisponivel. Contudo, nada impede que se utilize a expressão "legítima" para designar a quota de cada um desses herdeiros (letra "c", supra), desde que observadas as diferenças resultantes do emprego da mesma expressão com outro significado, não mais referindo-se à metade dos bens, e sim à quota distribuida a cada herdeiro legítimo segundo a proporção fixada em lei.
De outra parte, a intangibilidade da legítima protege os herdeiros necessários não apenas contra a livre disposição dos bens através de testamento, mas também contra a liberalidade por ato inter vivos. Portanto, mesmo inexistindo testamento, pode ser necessário fazer valer a garantia da legítima com o objetivo de reduzir as doações inoficiosas, isto é, os atos de liberalidade praticados em vida que violam a quota reservada aos herdeiros necessários.

A intangibilidade da legítima assegurada pelo ordenamento jurídico brasileiro, porém, é meramente quantitativa.? Isso significa que os herdeiros necessários não têm o direito de exigir metade dos bens de cada natureza, ou metade dos bens de certa qualidade. Somente podem exigir seja respeitada uma igualdade quantitativa na partilha, isto é, que a soma dos valores correspondentes aos bens integrantes da legítima seja equivalente à soma dos valores alusivos aos bens objeto de livre disposição.

Apesar de parte da doutrina não concordar com o posicionamento aqui exposto, entre eles Carvalho Santos, ${ }^{8}$ entendemos que a lei brasileira não

7 Nesse sentido: PONTES DE MIRANDA, Tratado..., v. 56, p. 90. Quanto à diferenciação entre intangibilidade quantitativa e qualitativa, recomenda-se a leitura de D'AVANZO, Walter. Delle successioni. Firenze: G. Barbèra, 1941, v. 2, p. 420-426.

8 "Não nos parece que a razão esteja com essa jurisprudência. Em verdade, não há um dispositivo expresso proibindo ao testador determinar os bens que devem constituir o quinhão do herdeiro necessário, correspondente à sua legítima, mas essa proibição está implícita dentro do sistema do Código, quando exige no partilhar os bens a observância da maior igualdade possível, quanto ao seu valor, natureza e qualidade (art. 1.775)" (SANTOS, J. M. de Carvalho. Código Civil brasileiro interpretado. 8. ed. Rio de Janeiro: Freitas Bastos, 1960, v. 24., p. 86). Expressamente concordando com Carvalho Santos: MIRANDA, Da "legitima"..., p. 152. 
admite outra interpretação da matéria. Afinal, em relação às disposições testamentárias o legislador expressamente optou por permitir que o testador determinasse especificamente os bens que deixa ao sucessor (legado) ou simplesmente estabelecesse a quota da herança que atribui ao beneficiado. Inexistindo qualquer obstáculo ao preenchimento da metade disponível com a instituição de legados, ou mesmo com a transmissão de bens determinados através de liberalidades inter vivos, inegável que o disponente possuirá a faculdade de escolher os bens que comporão a legítima. Entretanto, frise-se que em nenhuma hipótese lhe é permitido atingir a reserva. Se a soma dos bens escolhidos para integrar a parte disponível da herança superar a metade garantida por lei em favor dos herdeiros reservatários, haverá a necessária redução das disposições.

Um problema se coloca quando os reservatários pretendam aceitar a violação da legítima: poderiam os herdeiros necessários dispensar a redução, cumprindo integralmente a vontade declarada pelo testador? Sem dúvida. Em se tratando de direitos disponíveis, os respectivos titulares gozam da prerrogativa de renunciá-los. A questão, porém, ganha contornos mais duvidosos em virtude do disposto no art. 1.808, caput, do Código Civil de 2002. ${ }^{9}$ Diante dessa norma, resta vedada a possibilidade de renúncia parcial da herança, e, por consequiência, de uma parcela da legítima. Para compatibilizarmos a disponibilidade sobre esses direitos patrimoniais e a proibição de renúncia ou aceitação parcial da herança, devemos diferenciar dois momentos sucessivos: inicialmente, tem-se a transmissão integral da legítima, de forma automática, para os herdeiros necessários; apurado o excesso e concordando os reservatários em respeitar a vontade do falecido, deve-se então considerar que houve uma transmissão patrimonial dos herdeiros necessários para os sucessores testamentários beneficiados. ${ }^{10}$

Admitida essa transmissão patrimonial, basta verificar se houve ou não a correspondente reposição por parte dos beneficiados para detectarmos se a operação foi realizada a título gratuito ou oneroso, com a consequiente incidência do tributo relativo à transação efetuada.

Quanto ao cálculo da legítima, notese que o Código Civil Brasileiro de 2002, reproduzindo dispositivos do anterior, em mais de uma oportunidade menciona que a legítima corresponde à metade do patrimônio hereditário (arts. $1.789 \mathrm{e}$ 1.846). Entretanto, o que sempre se viu foi uma divisão em "duas metades de tamanhos diferentes". Realmente é complicado abordar e procurar explicar esse aspecto da matéria, pois contraria

\footnotetext{
9 "Art. 1.808. Não se pode aceitar ou renunciar a herança em parte, sob condição ou a termo." 10 LACERDA, Galeno Vellinho. Sucessões e partilhas. Rio de Janeiro: Forense, 2000, v. 4 , p. 225-242.
} 
a lógica admitir que duas metades de uma mesma coisa não sejam quantitativamente idênticas.

Importante observar, antes de tudo, a redação conferida ao parágrafo único do art. 2.002 do novo Código Civil: "Para cálculo da legítima, o valor dos bens conferidos será computado na parte indisponível, sem aumentar a disponível". Ora, se existe previsão de que o valor de determinados bens seja somado com a finalidade de aferir a metade disponível e ao mesmo tempo se admite que o aumento daí decorrente não implicará em majoração da outra metade, a única alternativa é reconhecermos que o legislador efetivamente contrariou a lógica e estabeleceu a possibilidade de existirem duas metades desiguais."

$\mathrm{O}$ art. 1.847 do novo Código Civil, apesar de conter redação diversa à do art. 1.722 do Diploma de 1916, ${ }^{12}$ aparentemente manteve a orientação manifestada no dispositivo revogado: "Art. 1.847. Calcula-se a legítima sobre o valor dos bens existentes na abertura da sucessão, abatidas as dívidas e as despesas do funeral, adicionando-se, em seguida, o valor dos bens sujeitos à colação."
O critério seguido apresenta dois inconvenientes, o primeiro deles há muito superado pela doutrina no plano abstrato, embora de difícil (mas não impossível) aplicação: estamos falando na possibilidade de ocorrerem doações (atos inter vivos) sucessivas, caso em que, para viabilizar a averiguação de eventual violação à legítima, temos que somar os valores correspondentes a cada um dos bens doados e posteriormente comparar o resultado obtido com o valor dos bens preservados em favor dos herdeiros necessários. A grande dificuldade para aplicar tal orientação decorre de que é indispensável demonstrar quais bens foram doados, quando ocorreu cada ato de liberalidade, etc., além da necessidade de comprovar todas essas transmissões patrimoniais, muitas das quais poderão ter ocorrido há várias décadas.

O segundo inconveniente que decorre do sistema adotado pelo Código Civil brasileiro melhor pode ser explicado através de um exemplo bastante esclarecedor: imagine-se duas pessoas casadas entre si pelo regime da comunhão universal de bens. ${ }^{13}$ possuindo

\footnotetext{
11 MIRANDA, Da "legítima"..., p. 151-152. Ainda sobre o tema MELO, Luiz Pereira de. Dos herdeiros necessários. Jurisprudência e Doutrina, Fortaleza, v. 91, p. 23/28, 1973, p. 25.

12 Dizia o art. 1.722 do antigo Código: "Art. 1.722. Calcula-se a metade disponível (art. 1.721 ) sobre o total dos bens existentes ao falecer o testador, abatidas as dívidas e as despesas do funeral." "Parágrafo único. Calculam-se as legítimas sobre a soma que resultar, adicionando-se à metade dos bens que então possuía o testador a importância das doações por ele feitas aos seus descendentes (art. 1.785).

13 Utilizamos o regime da comunhão universal de bens apenas por se tratar de um dos casos em que o cônjuge supérstite não concorrerá à herança com os descendentes.
} 
filhos comuns. Ao atingirem uma idade bastante avançada, os pais resolvem doar conjuntamente aos descendentes a quase totalidade do patrimônio que lhes pertence, apenas reservando em favor próprio alguns poucos bens de valor irrisório se comparado ao dos bens transmitidos por liberalidade. Feito isso, cada um dos cônjuges elabora testamento atribuindo ao outro a ínfima parcela remanescente do patrimônio comum. Nesse caso, se interpretarmos a lei de forma literal e restrita, concluiríamos que o testamento do primeiro cônjuge a falecer violou a legítima dos herdeiros necessários, pois não preservou, em favor destes, a metade dos bens existentes na data de abertura da sucessão. Esse raciocínio, porém, não nos parece correto. Na hipótese aludida, a legítima dos herdeiros necessários não apenas foi garantida como também foi antecipada, inclusive proporcionando maior vantagem aos reservatários, que mais cedo poderão começar a usufruir do patrimônio transmitido.

Pelas razões expostas, entendemos ser extremamente injusta e inadequada a interpretação restrita aludida acima, devendo o aplicador da lei conferir o devido temperamento à norma que, interpretada literalmente, não apenas deixaria de cumprir a finalidade em função da qual foi estabelecida, mas também se voltaria contra aqueles que visava proteger. Afinal, diante da probabilidade de que, no futuro, a questão fosse decidida da forma que condenamos, os pais simplesmente deixariam de antecipar a transmissão do patrimônio aos filhos.

\section{HERDEIROS NECESSÁRIOS SEGUNDO O NOVO CÓDIGO CIVIL}

Conforme abordado superficialmente no capítulo anterior, os herdeiros legítimos podem ser subdivididos em facultativos e necessários. Os primeiros não possuem qualquer garantia contra a vontade do testador em afastá-los da herança, ao contrário dos últimos, a quem a lei reserva uma metade indisponível do patrimônio.

Todavia, a partir dessa subdivisão e considerando a sucessão legítima como contraposta à testamentária, seria incorreto concluir que os herdeiros necessários não possam ser contemplados por ato de última vontade. Aliás, o art. 1.849 do Código Civil de 2002 expressamente autoriza a cumulação da quota legítima com legado ou quota do disponível conferida por testamento. Evidente que a manifestação de última vontade na qual simplesmente seja concedida aos herdeiros necessários a parte disponível do patrimônio, na mesma proporção fixada pela lei, seria totalmente desnecessária, uma vez que os arts. $1.788,2^{\mathrm{a}}$ parte, e 1.966 do novo Código Civil conferem aos herdeiros legítimos (e os necessários sempre estarão à frente dos facultativos na ordem de vocação hereditária) a parte disponível que não foi objeto de testamento. Além disso, a regra geral é que os herdeiros necessários só podem perder com a elabora- 
ção de testamento. ${ }^{14}$ Essa afirmação é verdadeira se considerarmos o conjunto de herdeiros reservatários, mas não se pensarmos na possibilidade de contemplação somente de alguns dos herdeiros necessários quanto à parte disponível, hipótese em que estes seriam beneficiados em comparação ao que receberiam em caso de sucessão intestada.

A diferença básica entre os herdeiros facultativos e os reservatários consiste na possibilidade de serem aqueles afastados da sucessão através de simples manifestação de vontade imotivada do testador, enquanto o afastamento dos reservatários somente poderá ocorrer quando configurado algum dos graves casos previstos na legislação como autorizadores da deserdação ou mesmo de indignidade. Quanto a esta última, tanto os herdeiros necessários quanto os facultativos estão sujeitos a ela. A deserdação, por outro lado, serve apenas como meio de afastar da sucessão os herdeiros necessários, uma vez que é dispensável qualquer motivação para deixar de contemplar em testamento os herdeiros facultativos, como dispõe o art. 1.850 do Código Civil atual. ${ }^{15}$ $\mathrm{O}$ instituto da deserdação, que poderia ser tomado como prejudicial aos herdeiros necessários por consistir em modo de afastá-los da sucessão, em verdade os protege contra o arbítrio do testador, pois a lei estabelece um rol taxativo e reduzido de causas que poderiam ensejá-lo, impedindo sejam os herdeiros necessários afastados por qualquer outra justificação ou mesmo imotivadamente.

14 Essa constatação decorre do fato de que, inexistindo testamento, aos herdeiros necessários será transmitida a totalidade do patrimônio hereditário. De forma alguma poderiam eles herdar quantidade superior a esta. As disposições de última vontade, em tese, somente poderiam thes ser prejudiciais, reduzindo as respectivas participações no acervo. Convém, todavia, ressalvar certas exceções: a clausulação do patrimônio transmitido causa mortis, por exemplo, pode ser benéfica ao herdeiro necessário que está prestes a propor dissolução da sociedade conjugal, como forma de impedir que o patrimônio hereditário se comunique ao outro cônjuge; a cláusula de impenhorabilidade também pode garantir ao reservatário a propriedade de bens inalcançáveis por seus credores; o testamento que simplesmente deserda algum dos herdeiros necessários acarretará o aumento do quinhão de cada um dos demais reservatários; etc.

15 "Art. 1.850. Para excluir da sucessão os herdeiros colaterais, basta que o testador disponha de seu patrimônio sem os contemplar." Aqui convém destacar uma omissão do legislador, em nosso entender, relativamente ao companheiro estável, não arrolado entre os herdeiros necessários e, conseqüentemente, herdeiro não obrigatório. Mais correta seria a redação do art: 1.850 se fizesse referência simplesmente aos herdeiros facultativos, e não especificamente aos colaterais. Entretanto, como destaca Sílvio Rodrigues, o dispositivo em comento é absolutamente desprovido de utilidade, já que a conseqüência prevista decorreria automaticamente do sistema estabelecido pelo Código, segundo o qual a garantia da reserva somente beneficia os herdeiros necessários. RODRIGUES, Direito..., p. 124. 
Passemos agora ao elenco dos herdeiros reservatários fixado pelo novo Código Civil.

Seguindo orientação já constante do Projeto Beviláqua (de 1889), porém não adotada pelo Código Civil de 1916, o legislador de 2002 optou por atribuir ao cônjuge a condição de herdeiro necessário, ao lado dos descendentes e ascendentes, que já gozavam de tal benefício sob a égide do diploma anterior. Mais do que isso, alterou em parte a ordem de vocação hereditária para efeito de estabelecer concorrência entre o cônjuge e os descendentes em determinados casos, bem como entre o cônjuge e os ascendentes do de cujus.

Por óbvio, a qualidade de herdeiro necessário conferida ao cônjuge pelo art. 1.845 está condicionada ao disposto no art. 1.830 do novo Código Civil, que expressamente retira qualquer direito sucessório daquele consorte se, ao tempo da morte, estivessem separados judicialmente ou separados de fato há mais de dois anos, "[...] salvo prova, neste caso, de que essa convivência se tornara impossível sem culpa do sobrevivente".

Importante destacar, ainda, a obrigatoriedade de estudo conjunto das disposições atinentes aos herdeiros necessários e das normas relativas à ordem de vocação hereditária, pois, em última análise, somente caberia falar em ascendentes como herdeiros neces- sários, por exemplo, quando inexistissem descendentes, caso contrário estariam aqueles automaticamente afastados da sucessão. O mesmo raciocínio aplica-se ao cônjuge sobrevivente quando configurada qualquer das exceções à concorrência com os descendentes mencionadas no art. 1.829 , inciso I, do novo Código. ${ }^{16}$ Conclui-se, então, que a condição de herdeiro necessário em determinado caso concreto fica condicionada à inexistência de sucessor que the anteceda segundo a ordem de vocação hereditária estabelecida pela lei civil.

Quanto ao companheiro estável, parece-nos equivocada a assertiva de que o mesmo goze da condição de herdeiro necessário. Em síntese, poderíamos relacionar os seguintes argumentos para demonstrar que o convivente não foi alçado a essa condição pelo art. 1.790 do Código Civil de 2002: a) ao relacionar os herdeiros necessários (art. 1.845), o legislador estabeleceu rol taxativo, razão pela qual a ausência de menção ao companheiro já seria suficiente para embasar nosso posicionamento; b) a imperatividade que poderia ser atribuída ao art. 1.790 em virtude da sua redação ("A companheira ou o companheiro participará ...") é só aparente, seguindo a mesma estrutura do art. 1.839 ("Se não houver cônjuge sobrevivente, nas condições estabelecidas no art. 1.830 , serão

16 O referido dispositivo exclui da concorrência com os descendentes a pessoa casada com o falecido pelo regime da comunhão universal ou da separação obrigatória de bens, assim como quem fosse casado com o de cujus pelo regime da comunhão parcial nos casos em que o autor da herança não deixar bens particulares. 
chamados a suceder os colaterais até o quarto grau."), alusivo aos parentes colaterais, inquestionavelmente herdeiros facultativos. Em ambos os casos, os verbos estão conjugados no futuro de forma incondicionada, mas esse aspecto é insuficiente para alçar o companheiro à condição de herdeiro necessário, tanto que o mesmo tempo verbal é utilizado no dispositivo atinente aos colaterais e ninguém até hoje pretendeu interpretar essa norma de modo a incluí-los entre os herdeiros necessários; c) admitir que a legislação brasileira tenha pretendido tornar o companheiro estável herdeiro reservatário causaria, ainda, sérias distorções, dispensando-se à ele tratamento diferenciado e mais benéfico do que o dispensado ao cônjuge. Note-se que o dever de colacionar, por exemplo, é imposto apenas aos descendentes e ao cônjuge sobrevivente, conforme o art. 2.003 do novo Código. Admitindo-se o companheiro como herdeiro necessário, estaria o mesmo dispensado de colacionar os bens recebidos do autor da herança ainda em vida. Esse tratamento privilegiado conferido ao companheiro seria, ao nosso ver, incompatível com o sistema jurídico brasileiro. Importante salientar, também, que o companheiro, ao contrário do cônjuge, não foi referido no art. 544, correspondente às doações em adiantamento de legítima, ausência que reforça o entendimento exposto neste trabalho; d) seria incongruente por um lado considerar herdeiro reservatário o companheiro e por outro incluí-lo na ordem de vocação hereditária depois de herdeiros facultativos, isto é, dos colaterais. Conforme mencionado anteriormente, $\mathrm{o}$ herdeiro que recebe da lei a qualificação de "necessário", independentemente disso só herdará na falta de outros sucessores que lhe antecedam na ordem de vocação. Assim, os ascendentes só sucedem quando o de cujus não deixa descendentes. O companheiro estável também só recebe a totalidade da herança quando inexistirem parentes sucessíveis, aqui incluídos os colaterais (herdeiros facultativos), consoante dispõe o inciso IV do art. 1.790 .

Independentemente de todas as razões referidas acima, embasadas na lei posta, poder-se-ia argumentar que o "esquecimento" do legislador ao não referir os companheiros estáveis entre os herdeiros necessários deve ser sanado o quanto antes, mediante alteração legislativa. Um aspecto, porém, não pode ser abstraído ao comentarmos essa sugestão: a união estável caracterizase pela ocorrência de certas condições ao longo de determinado período, tendo início sempre impreciso, dificilmente determinável com exatidão. Muitas vezes os próprios conviventes não sabem se o relacionamento que possuem caracteriza ou não uma união estável. $\mathrm{O}$ que dizer então de terceiros? Note-se que a proteção aos herdeiros necessários não está limitada apenas ao direito sucessório, pois a legítima também é assegurada contra a prática de atos inter vivos que pudessem violála. Imagine-se o enorme prejuízo à segurança das relações jurídicas caso a lei possibilitasse a anulação de doações que qualificaríamos como inoficiosas por ofensa à legítima do companheiro estável. 
Um último argumento poderia ser levantado para questionar o nosso posicionamento. Efetivamente, o art. 1.850 do Código Civil de 2002 deixou de mencionar o companheiro estável, fazendo alusão somente aos colaterais. Contudo, essa constatação em nada prejudica o raciocínio desenvolvido até aqui. Já dissemos que o dispositivo em pauta é totalmente despiciendo, porque seu conteúdo está implícito no sistema jurídico brasileiro, segundo o qual apenas os herdeiros necessários estão garantidos contra o arbítrio do testador que pretendesse excluí-los totalmente da herança.

De qualquer forma, apesar de todos os argumentos trazidos, é inquestionável que a não inclusão do companheiro estável entre os herdeiros necessários, em última instância, consiste em mera escolha legislativa, razão pela qual poderia ser modificada a qualquer momento, derrubando completamente o raciocínio exposto acima. Entretanto, no presente trabalho não pretendemos estudar os herdeiros necessários de forma claramente contrária ao disposto na lei, limitando nossa tarefa a interpretar o ordenamento jurídico vigente do modo que nos parece mais plausível e reconhecendo nossa total falta de legitimidade para criar disposições legais diversas das postas, ainda mais em se tratando de tema extremamente controvertido na sociedade brasileira contemporânea.

\section{A COLAÇÃO NA PERSPECTIVA DO NOVO CÓDIGO CIVIL}

Freqüentemente se ouve dizer que o instituto da colação tem por fim igualar as legítimas dos herdeiros necessários. Duas observações, contudo, devem ser feitas para que se alcance a verdadeira definição do instituto, bem como sua finalidade. Primeiro, destaque-se que nem todos os herdeiros reservatários estão obrigados a conferir o valor das doações recebidas do autor da herança. Os ascendentes, ao contrário dos descendentes, estão dispensados de fazê-lo. O cônjuge supérstite, por sua vez, apenas deverá conferir os bens que the foram doados em vida pelo de cujus quando concorrer com descendentes do mesmo. A justificativa dessa diferenciação é lógica: considerando que o instituto em pauta tem como finalidade igualar as legítimas, exigir a colação por parte de uns e não de outros herdeiros concorrentes seria medida extremamente injusta. Portanto, o cônjuge terá a obrigação de colacionar nos casos em que concorrer com descendentes do falecido, jamais quando concorrer com ascendentes. Na hipótese de inexistirem tanto descendentes quanto ascendentes, é óbvio que o cônjuge sobrevivente também estará dispensado de colacionar, pois nesse caso haverá um único herdeiro necessário, razão pela qual não se pode falar em "igualar legítimas".

Uma segunda observação também poderá influenciar certa flexibilização do conceito tradicional de "colação". Pois bem, note-se que o instituto era caracterizado em nosso direito anterior (Código Civil de 1916) como algo tendente a igualar as legítimas dos herdeiros necessários, mais especificamente dos descendentes. Ocorre que o Código de 
2002 inovou o direito sucessório pátrio em alguns aspectos, entre os quais podemos mencionar a previsão de concorrência do cônjuge com descendentes ou ascendentes do falecido. Como consequiência dessa alteração, foram estabelecidas quotas às vezes desiguais para as classes que concorrem numa mesma sucessão. Diante de tais circunstâncias, não mais se pode falar de modo absoluto em "igualar" legítimas, pois a quota destinada a cada um dos descendentes pode ser diferente da conferida ao cônjuge. Nesse sentido, aliás, merece elogios a redação do art. 2.003 do atual diploma, que tratou da matéria de forma precisa ao dispor: "A colação tem por fim igualar, na proporção estabelecida neste Código, as legítimas dos descendentes e do cônjuge [...]".

Não pretendemos esgotar a análise das colações no presente trabalho, e sim apenas ressaltar as principais alterações introduzidas pelo novo diploma Civil. Por essa razão, passaremos a abordar um último ponto relativo a esse instituto que nos parece relevante em face da recente modificação legislativa. Tratase do valor pelo qual os bens anteriormente doados serão conferidos após a abertura da sucessão.

Estabelecia o art. 1.792, caput, do Código de 1916: "Os bens doados, ou dotados, imóveis, ou móveis, serão conferidos pelo valor certo, ou pela estimação que deles houver sido feita na data da doação". O dispositivo transcrito foi objeto de inúmeras críticas por parte da doutrina brasileira. Mais questionável ainda a regra se considerada a galopante inflação que por tantos anos caracterizou a economia de nosso país. Afinal, o valor atribuído a determinado bem na data da doação certamente se tornaria irrisório em breve, sendo muito inferior ao que se precisaria gastar parà adquirir o mesmo bem poucos dias mais tarde.

As inúmeras críticas foram consideradas quando da elaboração do Código de Processo Civil, em virtude do que este diploma alterou o critério de cálculo do valor dos bens trazidos à colação: "Os bens que devem ser conferidos na partilha, assim como as acessões e benfeitorias que o donatário fez, calcular-se-ão pelo valor que tiverem ao tempo da abertura da sucessão". ${ }^{17}$

Sem dúvida este é o critério mais adequado para a regulação da matéria. Inquestionavelmente, para que a estimativa de valores de diversos bens alcance resultados eqüitativos, deve ser realizada segundo os mesmos critérios de avaliação e tomando por base o valor dos vários bens em uma mesma época. ${ }^{18}$

Entretanto, a tão comemorada alteração introduzida pela Lei Processual teve

\section{Parágrafo único do art. 1.014.}

18 "Daí resulta como consequiência que a avaliação dos bens deve ser homogênea, coetânea. Vedado se torna ao testador, por exemplo, impor valores ao seu talante aos bens da herança, assim como não poderá o juiz, sob pena de nulidade, partilhar bens com avaliação diversa no tempo." (LACERDA, Sucessões...). 
vida curta, sendo vítima de retrocesso imposto pelo Código Civil de 2002, que assim disciplinou a questão: "Art. 2.004. O valor de colação dos bens doados será aquele, certo ou estimativo, que thes atribuir $\mathrm{o}$ ato de liberalidade". E continua no $\S 1^{\circ}$ : "Se do ato de doação não constar valor certo, nem houver estimação feita naquela época, os bens serão conferidos na partilha pelo que então se calcular valessem ao tempo da liberalidade".

Embora a questão inflacionária não mais acarrete a imensa preocupação de outrora, em função da relativa estabilidade alcançada por nossa economia, de qualquer forma mostra-se conveniente a imediata alteração do dispositivo em pauta pelas razões expostas acima, especialmente pelo desequilíbrio que proporciona, ainda mais em se tratando de instituto que tem por objetivo exatamente "igualar" as legítimas de certos herdeiros necessários.

\section{CLAUSULAÇÃO DE BENS DA LEGÍTIMA}

A imposição das cláusulas de inalienabilidade, impenhorabilidade e incomunicabilidade sobre o patrimônio hereditário há muito vem sendo alvo de críticas por parte dos juristas, os quais arrolam inúmeros prejuízos gerados pela clausu- lação, especialmente no que tange à inalienabilidade. Apenas para citar algumas dessas desvantagens, podemos elencar: a retirada de bens do comércio, impedindo a livre circulação dos mesmos; ${ }^{19} \mathrm{o}$ desinteresse que em vários casos o sucessor passa a ter pelo bem, muitas vezes já em estado precário, necessitando de reparos, porém sem a perspectiva de poder aliená-lo dentro de certo tempo e se ver ressarcido das despesas realizadas; quando imposta a cláusula sobre bens que compõem a legítima, pode implicar em verdadeira redução da garantia conferida pela lei aos herdeiros necessários, correndo o risco, inclusive, de ser utilizada como uma forma de perseguição ou de castigo ao sucessor; etc.

Todavia, apesar dos muitos inconvenientes apresentados, a clausulação em algumas hipóteses mostra-se não apenas adequada mas também necessária para proteger os interesses do sucessor. ${ }^{20} \mathrm{Com}$ base nesse pensamento, $\mathrm{o}$ legislador de 2002 manteve a possibilidade de clausulação dos bens que integram o patrimônio hereditário, inclusive permitindo que tais cláusulas incidissem sobre a metade indisponível.

Se a própria existência das cláusulas de inalienabilidade, impenhorabilidade e incomunicabilidade já causa extrema repugnância a inúmeros autores,

19 Sobre as objeções econômicas à inalienabilidade dos bens: MALUF, Carlos Alberto Dabus. Cláusulas restritivas nas disposições testamentárias. Revista dos Tribunais, São Paulo, n. 482, p. 29-40, dez. 1975, p. 31.

20 Eugênio Callioli apresenta vários casos em que a clausulação mostra-se conveniente, os quais deixamos de reproduzir em virtude de não terem ligação direta com o escopo do presente trabalho: (CALLIOLI, Cláusulas... p. 74-75). 
imagine-se quando a imposição das mesmas ocorrer sobre quota da herança $a^{21}$ que a lei considera intangível, mesmo contra a vontade do testador.

Porém, o regramento da questão evoluiu de forma substancial com a entrada em vigor do novo Código Civil, embora ainda não se tenha atingido o que muitos entendem ser o ideal, isto é, o completo banimento dessas cláusulas. Ao menos em relação à legítima, parece claro que o legislador pretendeu condicionar a clausulação dos bens à criação de uma situação mais favorável ao herdeiro necessário. Entendemos, portanto, que o herdeiro reservatário poderá postular a anulação do gravame sobre os bens recebidos por falecimento do testador quando demonstrar, de forma clara, que a inalienabilidade, impenhorabilidade e/ou incomunicabilidade the serão prejudiciais. Esse, ao nosso ver, o real significado da expressão "justa causa" contida no art. 1.848 caput e $\$ 2^{\circ}$ do Código Civil brasileiro de 2002.

Importante salientar, contudo, que a identificação da cláusula como um favorecimento, uma proteção ao herdeiro reservatário, independe, por óbvio, da vontade declarada pelo interessado. Assim, as simples alegações do herdeiro de que pretende alienar o bem e de que isso representaria um grande negócio, somado ainda à afirmação de que ele (herdeiro), melhor do que qualquer outra pessoa, pode saber o que é mais vantajoso para si próprio, são absolutamente insuficientes para acarretar o levantamento do gravame.

Também a imposição das cláusulas fica condicionada a esse tipo de análise. É necessário verificar se o herdeiro é ou não favorecido pela instituição do gravame. Aqui, porém, entendemos conveniente esclarecer uma questão que envolve matéria processual, atinente à possibilidade de o juiz proceder ao levantamento dos gravames ex officio, no próprio Inventário, quando não vislumbrar motivos suficientes para justificar a imposição das cláusulas. Consideramos inadmissível tal atitude, pois nessa hipótese evidentemente a vontade do herdeiro necessário que teve seus bens atingidos deve ser seguida. Chegamos a essa conclusão partindo da idéia de que a garantia da legítima é algo estabelecido em benefício do herdeiro necessário, todavia podendo ele dispor livremente dos direitos patrimoniais que the forem conferidos.

Aliás, a permissão para que o juiz agisse de ofício (levantando o grava$\mathrm{me}^{22}$ ), além de desrespeitar o princípio da disponibilidade dos direitos patrimoniais, também daria ensejo ao pedido de terceiros (credores do herdeiro necessário, por exemplo) objetivando o levan-

\footnotetext{
21 Para ser mais preciso, melhor falar em imposição das cláusulas sobre "os bens que integram" a legítima (metade indisponível).

$22 \mathrm{Ou}$, para ser mais exato, impedindo que a clausulação dos bens realizada através de testamento produzisse seus normais efeitos.
} 
tamento das cláusulas e a viabilização de penhora sobre os bens.

Quando o próprio sucessor que estaria sendo prejudicado pela clausulação a aceita, não terá sentido nem cabimento decidir pelo levantamento de tais restrições. Procuraremos demonstrar, através de um exemplo bastante simples, a razoabilidade da posição que sustentamos: imposta a cláusula de incomunicabilidade sobre a legítima pertencente a uma filha do testador, com o objetivo de impedir a participação do seu marido nos bens transmitidos causa mortis, determinado juiz poderia entender que inexiste razão suficiente para tornar eficaz a cláusula, uma vez que o esposo da herdeira é pessoa notoriamente conhecida como bem sucedida nos negócios. Acontece que nem sempre o magistrado terá condições de captar a realidade de certa família. Talvez a cláusula houvesse sido imposta por testamento a pedido da própria sucessora, por estar em dúvida quanto à continuidade da sociedade conjugal. A decisão do juiz, nesse caso, além de violar a disponibilidade da parte sobre seus direitos patrimoniais, poderia causar sério constrangimento à interessada, que seria obrigada a recorrer de uma decisão apresentando argumentos que por certo colocariam um fim ao seu casamento.
O exemplo acima justifica, inclusive, a proposta de alteração legislativa contida no Projeto de Lei 6.960, que prevê a dispensa de "justa causa" para imposição da cláusula de incomunicabilidade, pois o próprio herdeiro necessário eventualmente pode se sentir compelido a postular a anulação do gravame simplesmente para satisfazer vontade do seu consorte, sem que também fosse esta a sua verdadeira intenção.

Ainda sobre a imposição de restrições à legítima, convém destacar mais uma novidade introduzida pelo novo Código, qual seja, a proibição de "[...] conversão dos bens da legítima em outros de espécie diversa", ${ }^{23}$ garantindo, dessa forma, que a participação do reservatário se dará sobre os bens que efetivamente compõem a herança, e não sobre quaisquer outros. ${ }^{24}$

Quanto à clausulação dos bens havidos pela via sucessória que possam ser incluídos na metade disponível, o testador continua com faculdade de impor livremente as cláusulas de inalienabilidade, impenhorabilidade e incomunicabilidade, conforme já ocorria no período de vigência do Código Civil de 1916. É o que se depreende da leitura do art. 1.848 , caput, do novo diploma.

Não se pode olvidar, porém, que a cada dia aumenta o número de decisões

\section{Art. $1.848, \S 1^{\circ}$.}

24 Convém destacar que a proibição em pauta é absoluta, sendo irrelevante a referência a qualquer "justa causa" que a fundamentasse. Pode-se dizer que o legislador sequer admite possa existir "justa causa" que torne conveniente a imposição desse tipo de restrição. Sobre o tema: LEITE, Eduardo de Oliveira. Comentários ao novo Código Civil. 3. ed. Rio de Janeiro: Forense, 2003. v. 21, p. 274. 
judiciais no sentido de permitir o levantamento dos gravames quando estes se mostrarem inadequados e injustificados, jurisprudência essa surgida ainda à luz do Código Civil antigo, que dispensava a "justa causa" para imposição das cláusulas em pauta. As três decisões do Tribunal de Justiça do Rio Grande do Sul a seguir transcritas bem demonstram essa tendência:

Inalienabilidade e incomunicabilidade. Cancelamento das cláusulas impostas em doação de imóvel. Caso concreto a autorizar o cancelamento do gravame, desaparecidas que estão as nobres finalidades de sua imposição, que agora se volta contra aqueles que objetivou proteger. Interpretação do art. 1.676 do CCB. ${ }^{25},{ }^{26}$

Apelação cível. Sucessões. Cláusula de inalienabilidade. Tal cláusula não pode ser vista de modo absoluto, devendo ceder em casos particulares de efetiva necessidade. Recurso desprovido. ${ }^{27}$

Doação. Cláusulas de inalienabilidade e impenhorabilidade. Cancelamento. Mitigação. Leitura da legislação infraconstitucional à luz dos princípios encartados na Lei Fundamental.
Relativização de direitos. Caso concreto. Frustração das expectativas que determinaram os gravames. Austeridade da regra civil superada pela conveniência ou vantagem concreta. Deferimento do pedido. - As regras de proibição contidas no estatuto civil merecem o devido temperamento, eis que a intenção de preservar o patrimônio, para a fruição dos descendentes, se subjuga à situação vigorante, diversa de quando foram estabelecidas as cláusulas, e o abrandamento da austeridade canônica mirase ña real conveniência ou vantagem para os interessados. Além disso, a leitura da legislação infraconstitucional deve ser feita sob a ótica dos valores fundamentais contidos na Carta Federal, para que ocorra a prevalência dos princípios nela contidos sobre normas elaboradas em outro século. Apelação provida, para autorizar o cancelamento de cláusula de restrição. ${ }^{2.8}$

Também o Tribunal de Justiça mineiro adotou semelhante posicionamento:

Testamento. Cláusula de incomunicabilidade, inalienabilidade e impenhorabilidade. Invalidação. Possibilidade - Tendo decorrido mais de vinte

25 Código Civil de 1916.

26 RIO GRANDE DO SUL. Tribunal de Justiça. Quinta Câmara Cível. Apelação Cível n 585046790. Relator: Des. Sérgio Pilla da Silva. Julgado em: 26 nov. 1985. Disponível em: $<$ http://www.tj.rs.gov.br $>$.

27 RIO GRANDE DO SUL. Tribunal de Justiça. Oitava Câmara Cível. Apelação Cível nº 70003128204. Relator: Des. Alfredo Guilherme Englert. Julgado em: 13 mar. 2003. Disponível em: $<$ http://www.tj.rs.gov.br>.

28 RIO GRANDE DO SUL. Tribunal de Justiça. Sétima Câmara Cível. Apelação Cível n 70002609295. Relator: Des. José Carlos Teixeira Giorgis. Julgado em: 06 jun. 2001. Revista Informatizada de Jurisprudência Jurisplenum, v. 71, n. 1, maio/jun. 2003. 
e cinco anos da abertura do testamento, e cessados todos os motivos da instituição da cláusula, pode a restrição ser abrandada, não só pelo contexto factual em que se encontra inserida, mas também em virtude da aplicação dos vários princípios que o sistema normativo encerra, os quais se amoldam ao caso. Recurso provido. Decisão reformada."

A tendência ilustrada pelas ementas reproduzidas acima dificilmente será revertida pela redação conferida ao art. 1.848 do novo Código Civil, que reiterou a permissão de livre imposição de cláusulas restritivas sobre a quota hereditária disponível. Melhor seria condicionar toda e qualquer clausulação de bens transmitidos hereditariamente à existência de "justa causa", ${ }^{30}$ obrigando que o gravame tanto sobre os bens integrantes da legítima quanto sobre os que compõem a quota disponível fosse justificado com base em razões plausíveis para que possa subsistir (ter eficácia) contra a vontade do sucessor que pela clausulação teria seus bens atingidos.
Quanto à indeterminação da expressão "justa causa", ${ }^{31}$ embora exija maior esforço interpretativo por parte do juiz, não nos parece seja inadequada ou excessivamente ampla, pois permite uma análise mais profunda em relação à finalidade das cláusulas, impedindo sejam as mesmas utilizadas de forma arbitrária pelo testador (ao menos no que diz com os gravames impostos sobre a legítima) e incompatível com o objetivo visado pela lei. Além disso, concede maior flexibilidade ao instituto, possibilitando ao juiz considerar de forma mais intensa os fatos concretos que a justificariam e a real utilidade do gravame.

Obviamente, a prova da "justa causa" em juízo não poderá ser oferecida pelo testador, ${ }^{32}$ dependendo da atuação de terceiro após a morte daquele. Considerando que muitas vezes a prova das alegações justificadoras da imposição das cláusulas encontra-se em poder dos próprios herdeiros necessários atingidos, não vemos outra solução exceto atribuir a estes últimos o ônus de provar que as razões mencionadas pelo testador não são verdadeiras.

29 MINAS GERAIS. Tribunal de Justiça. Quarta Câmara Cível. Apelação Cível $n^{\circ}$ 000.214.085-3/00. Relator: Des. Bady Curi. Julgado em: 07 abr. 2002. unânime. Revista Informatizada de Jurisprudência Jurisplenum, v 71, n. 1, maio/jun. 2003.

30 Excetuando-se apenas a cláusula de incomunicabilidade, conforme o Projeto de Lei 6.960 , pois a justificativa de tal restrição pode, muitas vezes, tornar conturbado um relacionamento conjugal até então tranqüilo.

31 MARTINS-COSTA, Judith. A boa-fé no direito privado: sistema e tópica no processo obrigacional. São Paulo: Revista dos Tribunais, 2000, p. 324-328.

32 Salvo documentos comprobatórios da causa justificadora do gravame, que poderão ser guardados pelos testador, mas não poderão ser por ele apresentados após seu passamento. Mesmo essa prova documental produzida com antecedência dependerá da "boa vontade" de alguém, que terá de levá-la ao conhecimento do juiz. 
Considerando que a imposição dos gravames de inalienabilidade, impenhorabilidade e incomunicabilidade derivam de circunstâncias muitas vezes diversas, ${ }^{3,3}$ oportuno lembrar sobre a possibilidade de o testador instituir equivocadamente uma dessas cláusulas, oferecendo motivação que apenas seria suficiente para justificar outro desses gravames. Entendemos, a princípio, que o juiz não pode determinar a imposição de cláusula diferente da prevista pelo autor da herança (por exemplo, trocar cláusula de incomunicabilidade por impenhorabilidade), exceto quando o gravame referido pelo testador consistir em restrição simplesmente mais ampla do que aquela que se poderia aplicar em razão dos motivos expostos na manifestação de última vontade. É o caso da inalienabilidade, que segundo expressa disposição legal, ${ }^{34}$ abrange a impenhorabilidade e a incomunicabilidade dos bens, pois nessa hipótese há uma relação de continência. Se o testador estabelecer a inalienabilidade porque o cônjuge de sua fillha é pessoa sabidamente infeliz nos negócios, caberia, então, a "redução" do gravame, restando apenas a incomunicabilidade sobre os bens.
Por fïm, entendemos que a expressão "justa causa" possui dois significados diferentes. No caput do art. 1.848 do novo Código Civil, a expressão é utilizada para designar os motivos capazes de ensejar a clausulação. O significado conferido a essa expressão no $\S 2^{\circ}$ do mesmo dispositivo é outro: aqui se trata de simples "justa causa para a alienação e posterior sub-rogação", isto é, para a substituição dos bens gravados. Parece claro que a última "justa causa" referida em nada se identifica com a primeira. Por exemplo: as precárias condições em que se encontra o imóvel gravado e a impossibilidade de reformá-lo justificam a alienação do bem, convertendo-se o produto da venda em outros que ficariam sub-rogados nos ônus dos primeiros; não justifica, todavia, o completo levantamento do gravame se o herdeiro continua com tendência à dilapidação do patrimônio. A modificação dessa característica desabonadora do sucessor (ou seja, sua "regeneração"), isto sim, justificaria o integral cancelamento da cláusula de inalienabilidade, hipótese em que sequer seria possível determinar a conversão do produto da venda em outros bens e posterior sub-rogação nos gravames.

\footnotetext{
33 Poderíamos mencionar como hipóteses clássicas justificadoras de cada uma dessas cláusulas: a) em relação à inalienabilidade, a tendência à dilapidação do patrimônio ou, em casos mais graves, a própria prodigalidade em sentido menos amplo; b) quanto à impenhorabilidade, a difícil situação econômico-financeira do sucessor, que tem o patrimônio em grande parte comprometido por dívidas; c) a incomunicabilidade, por sua vez, geralmente é motivada pelas características desabonadoras do cônjuge do herdeiro, ou mesmo pela circunstância de o casamento estar em situação periclitante.
}

34 Art. 1.911 do novo Código Civil brasileiro. 


\section{CONCLUSÃO}

A história dá conta, portanto, que a fixação da quota indisponível do patrimônio foi objeto de lenta e gradual evolução, partindo de dois extremos radicalmente opostos. No direito germânico, partiu-se da idéia de que não havia liberdade para testar em favor de pessoa estranha à família. No direito romano, ao contrário, inicialmente era conferida ampla liberdade ao testador para dispor de seus bens da forma como melhor the aprouvesse. Essas posições iniciais extremadas foram recebendo o devido temperamento ao longo dos séculos, chegando-se atualmente a um modelo intermediário: admite-se ampla liberdade de dispor de certa quota do patrimônio, mas também é garantida a participação dos reservatários sobre uma fração ideal da herança, da qual não poderão ser afastados, exceto se incorrerem em alguma das gravíssimas causas ensejadoras de deserdação ou indignidade.

A quota indisponível, no direito brasileiro, corresponde à metade do acervo hereditário. A essa porção dá-se o nome de legítima, no sentido de "reserva intangível fixada em favor dos herdeiros necessários".

Considerando que a garantia da legítima também se faz presente em relação a atos de liberalidade inter vivos, através dos quais poderia ser violada a reserva estabelecida, o legislador previu a impossibilidade de doar parcela do patrimônio superior ao que naquele momento poderia ser objeto de disposição testamentária. Além disso, determinou que certos herdeiros neces- sários colacionassem os bens recebidos do testador por ato inter vivos, como forma de igualar os quinhões desses sucessores, presumindo a lei que, na falta de referência expressa do doador, não quisesse atribuir vantagem a um desses herdeiros em prejuízo dos demais, e sim estivesse concedendo mera antecipação da legítima.

A garantia em pauta, todavia, é puramente quantitativa, já que ao testador é facultado instituir legados e doar bens certos durante sua vida, através do que pode escolher os bens que integrarão a legítima. Somente lhe é vedado dispor de bens cuja soma de valores supere a metade do seu patrimônio. Porém, essa limitação à liberdade do testador somente ocorre quando o mesmo possuir herdeiros necessários.

O critério utilizado tradicionalmente para calcular a parte indisponível causa estranheza sob dois aspectos: a) por admitir uma metade reservada maior que a metade disponível (o que contraria a lógica, ou no mínimo consiste em imprecisão), uma vez que o valor dos bens colacionados será computado ao calcular-se a primeira, sem contudo aumentar a segunda; b) pela injustiça causada em função de tomar-se como parte disponível do patrimônio apenas a metade dos bens existentes no momento da morte, sem considerar os bens antecipadamente transmitidos aos sucessores necessários. Considerando que a antecipação da legítima já constitui uma vantagem em favor dos herdeiros necessários, parece-nos injusto restringir a liberdade de disposição do testador apenas à metade dos bens existentes 
na data de abertura da sucessão, isso quando parte do patrimônio já houver sido transmitida anteriormente aos próprios reservatários.

Quando as disposições testamentárias violarem a legítima, será necessário reduzi-las, preservando os direitos assegurados aos reservatários. Em função da proibição de aceitar ou renunciar a herança apenas em parte, deve-se considerar que existe uma transmissão patrimonial do herdeiro necessário em favor do beneficiado pelo testamento sempre que o primeiro renuncia ao direito de ver preservada a quota indisponível, pois considera-se que aceitou a herança integralmente e cedeu parte dela ao abdicar do mínimo assegurado pela lei (reserva).

Quanto ao rol dos herdeiros necessários, o novo Código Civil incluiu entre os mesmos o cônjuge sobrevivente, desde que não separado judicialmente do falecido, nem separado de fato há mais de dois anos, exceto, neste caso, se comprovar que a convivência se tornou impossível sem culpa sua.

O companheiro estável, de outra parte, não pode ser considerado herdeiro reservatário segundo a legislação vigente, já que não mencionado no art. 1.845 do novo Código. Para que companheiro fosse elevado a essa condição seriam indispensáveis significativas mudanças em vários institutos do direito sucessório, pois, caso contrário, a ele seria dispensado tratamento diferente e mais benéfico se comparado ao cônjuge.

Tendo o legislador de 2002 estabelecido a concorrência sucessória entre os descendentes e o cônjuge supérstite quando atendidas determinadas circunstâncias, foi necessário adaptar os dispositivos referentes à colação e à doação em antecipação de legítima. Assim, restou o cônjuge obrigado a colacionar os bens recebidos do autor da herança por doação, mas apenas quando concorrer com descendentes do mesmo. Se concorrer com ascendentes, não haverá necessidade de conferi-los.

Ainda sobre a colação, saliente-se que o Código Civil de 2002 representou imenso retrocesso no que tange ao critério pelo qual serão estimados os bens conferidos. Ao contrário do Código de Processo Civil, que determinou fossem os bens calculados pelo valor que tivessem ao tempo da abertura da sucessão (ou seja, de forma idêntica ao que ocorreria em relação ao restante do patrimônio), o novo Código Civil estabeleceu que o valor de tais bens seria aquele, certo ou estimativo, atribuído no ato da liberalidade. A atual redação merece ser revista, pois estabelece critério desigual de avaliação dos bens.

Por fim, destacou-se a existência de certas restrições que podem ser impostas pelo testador até mesmo sobre a parte indisponível do patrimônio hereditário. O novo Código Civil, porém, restringiu em grande medida a possibilidade de imposição das cláusulas de inalienabilidade, impenhorabilidade e incomunicabilidade sobre a legítima, além de proibir expressamente que o testador determinasse a conversão dos bens que a compõem em outros de espécie diversa.

Diante das disposições do Código de 2002, a clausulação imposta aos 
bens da legítima somente poderá subsistir quando o testador apresentar "justa causa", isto é, demonstrar que o gravame não prejudica o herdeiro necessário, e sim o protege. Contudo, em função de o herdeiro poder dispor dos direitos adquiridos por herança, lhe será facultado anuir com o gravame imposto, não podendo o juiz proceder ao levantamento dos mesmos ex officio, sob pena de violar a natureza disponível de tais direitos.

\section{REFERÊNCIAS}

CALLIOLI, Eugênio Carlos. Cláusulas restritivas: inalienabilidade, impenhorabilidade, incomunicabilidade. Revista dos Tribunais, São Paulo, v. 627, p. 69-82, 1988.

CRIBARI, Giovanni. Sucessão testamentária - Herdeiros necessários - Força da legítima - Doação em vida: limites - Ações de empresa familiar holding: sobrevalor. Revista Forense, Rio de Janeiro, v. 331, p. 185/195, 1995.

D'AVANZO, Walter. Delle successioni. Firenze: G. Barbèra, 1941. v. 2.

FERREIRA, Luís Pinto. Tratado das heranças e dos testamentos. 2. ed. São Paulo: Saraiva, 1990.

GOMES, Orlando. Sucessões. 7. ed. atual. por Humberto Theodoro Júnior. Rio de Janeiro: Forense, 1998.

JOSSERAND, Louis. Derecho civil. Buenos Aires: Bosch, 1951. v. 3, t. 2, revisado e completado por André Brun, traduzido para o espanhol por Santiago Cunchillos y Manterola.

LACERDA, Galeno Vellinho. Sucessões e partilhas. Rio de Janeiro: Forense, 2000. v. 4.

LEITE, Eduardo de Oliveira. Comentários ao novo Código Civil. 3. ed. Rio de Janeiro: Forense, 2003. v. 21.

MALUF, Carlos Alberto Dabus. Cláusulas restritivas nas disposições testamen- tárias. Revista dos Tribunais, São Paulo, n. 482, p. 29-40, dez. 1975.

MARTINS-COSTA, Judith. A boa-fé no direito privado: sistema e tópica no processo obrigacional. São Paulo: Revista dos Tribunais, 2000.

MELO, Luiz Pereira de. Dos herdeiros necessários. Jurisprudência e Doutrina, Fortaleza, v. 91, p. 23/28, 1973.

MIRANDA, Darcy Arruda. Da "legítima" na sucessão testamentária. Revista Trimestral de Direito Privado, São Paulo, v. 1, p. 149-158, 1970.

PONTES DE MIRANDA, Francisco Cavalcanti. Tratado de direito privado. Rio de Janeiro: Borsoi, 1968. v. 55. v. 56.

RODRIGUES, Sílvio. Direito civil: direito das sucessões. $25^{a}$ ed. atual. por Zeno Veloso. São Paulo: Saraiva,'2002.

SANTOS, J. M. de Carvalho. Código Civil brasileiro interpretado. 8. ed. Riode Janeiro: Freitas Bastos, 1960. v. 16 v. 24.

VENOSA, Sílvio de Salvo. Direito civil: direito das sucessões. 3. ed. São Paulo: Atlas, 2003.

WALD, Arnoldo. Direito das sucessões. 12. ed. rev., ampl. e atual., com a colaboração do Prof. Roberto Rosas e da Profa. Débora Gozzo. São Paulo: Saraiva, 2002. 